\title{
Profiles of Assessment Systems Worldwide
}

\section{Educational Assessment in England}

\begin{abstract}
This profile explains the assessment system in England, concentrating on those aspects that are related to government policy. It begins by putting the system in context; it then describes the national educational structure, curriculum and assessment arrangements. The government agencies responsible for carrying out education policies are introduced. In order to illustrate the intersection of curriculum and assessment development and political policy, the profile describes and discusses assessment issues that highlight the role of government and its agencies in the development, implementation and monitoring of England's national curriculum tests and 14 to 19 qualifications. It argues that successive governments have increasingly intervened directly in curriculum and qualifications development, and observes the growing governmental policy influence over assessment issues and the repercussions of that influence.
\end{abstract}

\section{Background}

England is part of the United Kingdom (UK), which consists of England, Scotland, Wales (otherwise known as Great Britain) and Northern Ireland. Its area is $130,395 \mathrm{~km}^{2}$. The population in mid 2008 was 51.45 million, and has been steadily growing at a rate of $.5 \%$ per year since 2001 due to increases in births, decreases in deaths and migration in and out of the UK. People under the age of 16 make up 19\% of the population; those between 16 and retirement age make up 62\%; and those over retirement age make up $19 \%$. The population of elderly people is slightly larger than the under 16 year old population. Life expectancy at birth for 2006 - 2008 was 77.7 years for men and 81.9 years for women. England's ethnic composition across its entire population is $88 \%$ white, $5.7 \%$ Asian, $2.8 \%$ Black, $1.7 \%$ mixed race and $1.5 \%$ other ethnic groups (Office of National Statistics, 2009).

The UK is a constitutional monarchy with a parliament of two chambers (the House of Commons and the House of Lords), a prime minister, who is the leader of the majority party in the Commons, a Cabinet appointed by the prime minister and a judiciary. The Commons is more powerful than the Lords and has 650 elected members.

\section{The Education System in England}


England has a highly regulated centralised system of curriculum and assessment, with its government responsible for almost every aspect of schooling. In 2007 there were 8.15 million students in 25,018 schools in England, comprised of approximately four million primary students and four million secondary students (DCSF, 2008).

Since the end of the Second World War the English educational system has evolved in response to changes in society and the economy. Education up to the age of 15 was made compulsory in 1947; it was increased to 16 in 1972 and by 2015 all 17 and 18 year olds will have to be in some form of education or training (Teachernet, 2009). The national curriculum was introduced in 1988, which mandated that schools teach certain subjects and carry out certain assessments (Daugherty, 1995, O'Hear and White, 1993). Performance tables started to be compiled and published from 1997 that contained performance statistics about students' test and examination results for each school (Ray, 2006).

The qualifications that students undertake after the age of 14 also changed. The General Certification of Education (GCE) was introduced in 1951, replacing the School Certificate and Higher School Certificate. It was intended to cater for the increased range of subjects available to students since the raising of the school leaving age and to provide feedback on those subjects separately. The examinations were divided into Ordinary Level (O level) for 16 year olds and Advanced Level (A level) for 18 year olds. Certificates of Secondary Education (CSE) were introduced in 1965 to cater for 14 to16 year olds of lower ability than those targeted for O levels. In 1988 O levels and CSEs were replaced by the General Certificate of Secondary Education (GCSE), which catered to an even wider ability range.

\section{Educational Structure}

Education is compulsory for children between the ages of five and 16, although many students ${ }^{i}$ begin their schooling in reception classes at age four. All local authorities offer some form of pre-compulsory education, often working with the private and voluntary sectors. Most students move from primary to secondary school at age 11, and many secondary schools offer post-compulsory education for students aged 16 to 18 . There are also post-compulsory colleges, called Sixth Form and Further Education (FE) colleges, which cater for 16 to 18 year olds.

Schools are open 190 days a year; recommended weekly lesson times are 21 hours for five to seven year olds, 23.5 hours for eight to 11 year olds and 24 hours for 12 to 16 year olds. Class size is limited to 30 for the youngest students and classes are generally mixed ability in the primary phase (INCA, 2009). All schools are required to provide a broad and 
balanced curriculum and there are statutory requirements for particular subjects.

Compulsory schooling is divided into four key stages, topped and tailed by non-compulsory schooling, as shown in Table 1 (Isaacs and Colwill, 2005):

Table 1: Organisation of Schools in England

\begin{tabular}{|c|c|c|c|}
\hline Stage & Year/Grade & Typical age & Type of Institution \\
\hline \multirow{3}{*}{$\begin{array}{l}\text { Early Years } \\
\text { Foundation Stage }\end{array}$} & Pre-school and & $0-5$ & Pre-school settings \\
\hline & nursery education & & \\
\hline & Reception & $4-5$ & \multirow[t]{4}{*}{ Primary school } \\
\hline \multirow[t]{2}{*}{ Key Stage 1} & Year 1 & $5-6$ & \\
\hline & Year 2 & $6-7$ & \\
\hline \multirow[t]{4}{*}{ Key Stage 2} & Year 3 & $7-8$ & \\
\hline & Year 4 & $8-9$ & \multirow{3}{*}{$\begin{array}{l}\text { Primary school; } \\
\text { Middle school }\end{array}$} \\
\hline & Year 5 & $9-10$ & \\
\hline & Year 6 & $10-11$ & \\
\hline \multirow[t]{3}{*}{ Key Stage 3} & Year 7 & $11-12$ & \multirow{2}{*}{$\begin{array}{l}\text { Secondary school; } \\
\text { Middle school }\end{array}$} \\
\hline & Year 8 & $12-13$ & \\
\hline & Year 9 & $13-14$ & \multirow[t]{3}{*}{ Secondary school } \\
\hline \multirow[t]{2}{*}{ Key Stage 4} & Year 10 & $14-15$ & \\
\hline & Year 11 & $15-16$ & \\
\hline \multirow[t]{2}{*}{ Post compulsory } & Year 12 & $16-17$ & \multirow{2}{*}{$\begin{array}{l}\text { Secondary school; } \\
6^{\text {th }} \text { Form college; } \\
\text { Further Education } \\
\text { college }\end{array}$} \\
\hline & Year 13 & $17-18$ & \\
\hline
\end{tabular}

\section{Organisations responsible for governance of the educational system}

Some aspects of education in England are administered locally by 152 local authorities, but overall responsibility for education in England rests with two government departments; the Department for education (DoE) and the Department for Business, Innovation and Skills 
(BIS), the latter department's responsibilities are solely post-16, led by their respective secretaries of state. The department(s) responsible for education has changed over time, as shown in table 2. The title changes reflect the priorities of the government of the day and responsibilities of the departments.

Table 2: Departments of Education (DCSF, 2009g)

\begin{tabular}{|l|l|}
\hline \multicolumn{1}{|c|}{ Department Name } & \multicolumn{1}{|c|}{ Years } \\
\hline Department of Education and Science (DES) & $1964-1992$ \\
\hline Department for Education & $1992-1995$ \\
\hline $\begin{array}{l}\text { Department for Education and Employment } \\
\text { (DfEE) }\end{array}$ & $1995-2001$ \\
\hline Department for Education and Skills (DfES) & $2001-2007$ \\
\hline $\begin{array}{l}\text { Department for Children, Schools and } \\
\text { Families (DCSF) }\end{array}$ & $2007-2010$ \\
\hline Department for Education (DoE) & $2010-$ \\
\hline $\begin{array}{l}\text { Department for Innovation, Universities and } \\
\text { Skills (DIUS) }\end{array}$ & $2007-2009$ \\
\hline $\begin{array}{l}\text { Department for Business, Innovation and } \\
\text { Skills (BIS) }\end{array}$ & $2009-$ \\
\hline
\end{tabular}

From the early $20^{\text {th }}$ century agencies linked to governments, as shown in Table 3, have had responsibility for both curriculum and assessment development and implementation. The influence of those bodies has increased over time as successive governments introduced new, centrally controlled, curriculum and assessment instruments. This article largely concentrates on the years after 1988, which was a watershed that saw the operationalisation of the Education Reform Act, which introduced, among other things, the national curriculum and national tests for students aged 7,11 and 14. In the same year GCSEs were examined for the first time." Salter and Tapper see the late 1980s as the time when the government, through its Department of Education and Science, could both state and implement its centralising ambitions (Salter and Tapper, 1987).

At that time separate bodies were responsible for curriculum and assessment; the National Curriculum Council (NCC) and the School Examinations and Assessment Council (SEAC), respectively - interestingly, there was no vocational education body, although the National Council for Vocational Qualification (NCVQ) was established in 1986. In 1993 the two bodies merged to form the School Curriculum and Assessment Authority (SCAA). SCAA 
and NCVQ then formed the Qualifications and Curriculum Authority (QCA) in 1997, which recently - in 2009 - broke up into QCDA and Ofqual under the Apprenticeships, Skills, Children and Learning Act (OPSI, 2009). The recently elected Conservative-Liberal Democrat coalition government announced in June 2010 that it intends to abolish the QCDA.

Table 3: Advisory and regulatory bodies in England ${ }^{\mathrm{iii}}$

\begin{tabular}{|c|c|c|}
\hline Organisation & Responsibility & Dates \\
\hline $\begin{array}{l}\text { Secondary Schools Examinations } \\
\text { Council (SSEC) }\end{array}$ & Examinations & $\begin{array}{l}1917- \\
1964\end{array}$ \\
\hline Schools Council & Curriculum and Examinations & $\begin{array}{l}1964- \\
1984\end{array}$ \\
\hline $\begin{array}{l}\text { Schools Curriculum development } \\
\text { Committee (SCDC) }\end{array}$ & Curriculum & \multirow[t]{2}{*}{$\begin{array}{l}1984- \\
1988\end{array}$} \\
\hline $\begin{array}{l}\text { Secondary Examinations Council } \\
\text { (SEC) }\end{array}$ & Examinations & \\
\hline $\begin{array}{l}\text { National Council for Vocational } \\
\text { Qualifications (NCVQ) }\end{array}$ & Vocational curriculum and assessment & $\begin{array}{l}1986- \\
1997\end{array}$ \\
\hline National Curriculum Council (NCC) & Curriculum & \multirow{2}{*}{$\begin{array}{l}1988- \\
1993\end{array}$} \\
\hline $\begin{array}{l}\text { School Examinations and Assessment } \\
\text { Council (SEAC) }\end{array}$ & Assessment & \\
\hline $\begin{array}{l}\text { School Curriculum Assessment } \\
\text { Authority (SCAA) }\end{array}$ & Curriculum and Assessment & $\begin{array}{l}1993- \\
1997\end{array}$ \\
\hline $\begin{array}{l}\text { Qualifications and Curriculum Authority } \\
\text { (QCA) }\end{array}$ & $\begin{array}{l}\text { Curriculum and Assessment (including } \\
\text { vocational) }\end{array}$ & $\begin{array}{l}1997- \\
2009\end{array}$ \\
\hline $\begin{array}{l}\text { Qualifications and Curriculum } \\
\text { Development Agency (QCDA) }\end{array}$ & $\begin{array}{l}\text { Curriculum and Assessment } \\
\text { development (including vocational) }\end{array}$ & $2009-$ \\
\hline $\begin{array}{l}\text { Office of the Qualifications and } \\
\text { Examinations Regulator (Ofqual) }\end{array}$ & Regulation of tests and examinations & $2009-$ \\
\hline
\end{tabular}

The QCDA develops and advises ministers on the curriculum and related qualifications, improves and delivers assessments and reviews and reforms qualifications. It does this through: ensuring that the school curriculum prepares young people for the future; delivering National Curriculum tests, and developing methods for assessing students' progress; and reviewing and developing qualifications (QCDA, 2009). 
Ofqual reports directly to Parliament to improve public confidence in standards and regulates qualifications, examinations and tests in England by: ensuring that awarding organisations that offer and deliver qualifications have good systems in place, and that they are held to account for their performance; making sure that all qualifications offered by awarding organisations are fair and are comparable with other qualifications; monitoring standards in qualifications, exams and tests and reporting its findings; ensuring the quality of marking of exams, tests and other assessments to make sure that learners get the results their work deserves (Ofqual, 2009a).

As well as the curriculum and qualifications organisations, the other regulatory vehicle is the Office for Standards in Education, Children's Services and Skills (Ofsted), which regulates and inspects childcare and children's social care, schools, colleges, initial teacher education, work-based learning and skills training, adult and community learning, education and training in prisons and other secure establishments and the Children and Family Court Advisory Support Service. It was established in 1993 and carries out large numbers of inspections and regulatory visits of schools and colleges in England, reporting on the quality of teaching and administration (Ofsted, 2009).

Awarding bodies develop qualifications and their attendant examinations that Ofqual accredits. The government will not fund schools and colleges to offer qualifications that are not accredited. While there are 132 awarding organisations registered on the National Database of Accredited Qualifications (NDAQ), there are six main providers of qualifications for 14 to 19 year olds in England (NDAQ, 2009). They are the Assessment and Qualifications Alliance (AQA), the Council for the Curriculum Examinations and Assessment (CCEA), City and Guilds, Edexcel, Oxford, Cambridge and RSA (OCR) and the Welsh Joint Education Committee (WJEC).

The QCDA acts as an awarding organisation for the national curriculum tests although it outsources their development, generally to one or more of the awarding bodies above, and Ofqual regulates them.

\section{The National Curriculum and its assessment}

\section{Introduction of a National Curriculum}

Schoolchildren in England are subject to a highly regulated curriculum and assessment regime from the time they enter any educational setting, including pre-school. What they learn is spelled out in great detail, and they are constantly assessed to try to ensure that 
they have learned it. Until recently a child entering the system at age five could sit as many as 105 formal assessments before s/he left formal education at 18 , leading any number of critics to complain that English students were the most over-assessed children in the world (NUT, 2002). The following tries to explain how this came about.

Levin argues that education policy shares common themes across nations (Levin, 1998). Among these are that the need for change in education is largely couched in economic terms - with considerable attention being given to make schools more like businesses, that a sense of fear has replaced the sense of possibility as a driver for education change, that change is occurring in the context of large-scale criticism of schools and that an emphasis on standards, accountability and testing prevails, with test results used more and more publicly. This has certainly been the case in the national curriculum since its inception, with successive governments reinforcing their control over the curriculum and its assessment.

The Conservative party in the early 1980 s favoured an interventionist view in education. Its concerns included what was perceived to be falling standards in schools and children's relatively poor basic skills. (Machin and Vignoles, 2006). Sir Keith Joseph led this policy approach (Daugherty, 1995). Ball speaks of 'indirect evidence of the DES interest in an assessment-led mode of curriculum change and control' (quoted in Daugherty, 1995, p. 10). However, the mode of assessment was not set in stone in the earliest incarnation of the national curriculum.

In its 1987 consultation document the DES argued that a national curriculum and its associated assessment arrangements would help raise attainment standards by: ensuring that all pupils study a broad and balanced range of subjects; setting clear objectives for what children ... should be able to achieve; ensuring that all pupils ... have access to ... the same ... programmes of study which include the key content, skills and processes which they need to learn; and checking on progress toward those objectives and performance at various stages. (quoted in Torrance, 2002 p. 5)

A similar concern about standards of performance influenced the formation of the national curriculum's levels of attainment and attainment targets for each subject. The committee that the DES charged with recommending what the curriculum should look like and how it should be assessed, the Task Group on Assessment and Testing (TGAT), recommended 10 age-related levels of attainment, assessed by a variety of different means including tests, practical tasks and observation (DES,1987). The government's initial response to the TGAT 
report was sceptical, branding it complex, too reliant on formative assessment and expensive. Prime Minister Margaret Thatcher was more inclined to accept back-to-basics tests (Daugherty, 1995). The proposals, she said, were

a weighty, jargon filled document... The fact that [the report] was then welcomed by the Labour party, the National Union of Teachers and the Times Educational Supplement was enough to confirm for me that its approach was suspect. It proposed an elaborate and complex system of assessment - teacher dominated and uncosted (quoted in Whetton, 2009, p. 594).

Despite government reservations, many of the report's recommendations were implemented, albeit briefly.

The Education Reform Act (1988)

The Education Reform Act of 1988 enacted into law for the first time a national curriculum that comprised:

- the knowledge, skills and understanding which pupils ... are expected to have by the end of each key stage [attainment targets];

- the matters, skills and processes which are required to be taught to pupils ... during each key stage [programmes of study]; and

- the arrangements for assessing pupils at or near the end of each key stage for the purpose of ascertaining what they have achieved in relation to the attainment targets for that stage (OPSI, 1988).

It set out core and foundation subjects and defined the key stages and crucially enshrined within the powers of the Secretary of State for Education the authority to establish the national curriculum and revise that curriculum whenever s/he considered it necessary or expedient. These powers, and those delegated to the regulatory agencies on the secretary of state's behalf, have been used frequently over the last twenty years, fundamentally changing the character of national curriculum assessment on a number of occasions. A brief outline of the key stages is below, followed by a discussion of the implications of government policy.

\section{Early Years Foundation Stage}

Not envisaged in the late 1980s, pre-compulsory education for 0 to five year olds was enshrined in the 2006 Childcare Act (OPSI, 2006) and is offered as the Early Years 
Foundation Stage, which was introduced in 2008. Classes take place in school nursery departments, in dedicated nursery schools or in private settings. The curriculum is not subject based, but centred on early learning goals in six areas: personal, social and emotional development; communication, language and literacy; mathematical development; knowledge and understanding of the world; physical development; and creative development.

The 69 goals that children are supposed to achieve by age five are accomplished through planned purposeful play, with a balance of adult-led and child-initiated activities.

Early years providers are required to complete a profile for every child for whom they are responsible. This profile includes information on children's attainments across the six areas of learning and is based on the care giver's observation of daily activities. The information is passed on to parents and to year 1 teachers and is also used in a formative way during the foundation stage. The profile consists of 13 assessment scales, with up to nine points available on each scale. Aside from parent and receiving teacher use, the DCSF uses the outcomes of the assessments to evaluate the effectiveness of early years provision (DCSF, 2009i).

Key stages 1 to 3

In primary schools (reception through to year 6), in most cases one teacher teaches a class of students for all subjects; at the end of the year students move up to a new class and a new teacher. Primary teachers are supported by the government's primary strategy, which aims to strengthen the teaching of literacy and numeracy, while promoting a broad and balanced curriculum.

In most secondary schools ${ }^{\text {iv }}$ teachers teach subjects and groups of students move around the school and are taught each subject by a specialist teacher. The same children in each year group may not always be part of the same group for each subject, since subjects may be 'streamed' or 'set'. For example, there may be more than one mathematics class for each year group, with different classes for those with different abilities.

Key stage 1 to 4 students study the statutory national curriculum. Since its inception in 1988 the curriculum has been subsequently reviewed in 1993-95, 1998-2000, 2006-07 (key stage 3) and most recently in 2008-09 (primary). The pace of change reflects the political nature of England's curriculum and assessment policy. Secretaries of State want to be associated 
with improvements in standards and achievement, and use curriculum reviews as one of the vehicles to achieve these aims.

The most recent version of the curriculum can be found at www.curriculum/qcda.gov.uk. It contains a statement of aims, values and purposes for the curriculum as well as details on its main component subjects:

- English (core)

- Mathematics (core)

- Science (core)

- Art and design

- Citizenship

- Design and technology

- Geography

- History

- Information and communications technology

- Modern foreign language ${ }^{v}$

- Music

- Physical education

Students are required to study religious education. Key stage 3 students must also study careers and sex education. In 2006-2007 the QCA reviewed the key stage 3 curriculum in order to reduce prescription, increase flexibility, ensure a smoother transition for students from key stage 2 and on to key stage 4 and improve the transmission of non-core (foundation) subjects. All of the core and foundation subjects were kept, but were reorganised to stress the aims, key concepts and key content of each. The revised key stage 3 curriculum was introduced in September 2008, and featured a greater emphasis on numeracy, literacy and the development of personal, learning and thinking skills. It still retains subject specific programmes of study, many of which have prescribed content.

In 2009 an Independent Review of the Primary Curriculum led by Sir Jim Rose, former director of inspection at Ofsted, recommended that the primary curriculum is organised into six areas of learning, commencing in September 2011, with literacy, numeracy, ICT and personal development forming the new core:

- Understanding English, communication and languages 
- Mathematical understanding

- Scientific and technological understanding

- Historical, geographical and social understanding

- Understanding physical development, health and well-being

- Understanding the arts (DCSF, 2009d).

The impetus behind the review was to narrow the achievement gaps between disadvantaged children and their peers. Its remit was to simplify the primary curriculum and introduce the kinds of flexibilities available in the early years foundation stage and key stage 3 , but maintaining an emphasis on reading, writing, and numeracy (Balls, 2008). Within this new core the subjects listed above could remain intact. New programmes of study are not due until 2010. In June 2010 the newly-elected government removed this new curriculum from the QCDA website and initiated its own review.

\section{Assessing key stages 1 to 3}

Each national curriculum subject is divided into programmes of study for each key stage and attainment targets setting out national expectations for performance on an eight-level scale. National curriculum testing results in each child receiving a level in key subjects. Early manifestations of these assessments proved very time consuming and burdensome for teachers and were quickly reshaped in the early 1990s. Gipps argues that it was not simply the assessment burden that forced the change; rather it was a government intent of raising standards and forcing accountability of schools, coupled with a mistrust of teachers, which resulted in reliable and cheaper objective tests (Gipps, 1993). Over the course of the 1990s national curriculum assessment moved away from teachers' control and was transformed into written examinations in English, mathematics and science (proposed national assessments in other subjects were abandoned) taken by an entire year group simultaneously. At key stage 3 the then secretary of state, Kenneth Clarke, intervened directly and demanded terminal written examinations taken under controlled conditions (Daugherty, 1995).

Following a threatened boycott of the tests by some teachers' organisations, the government set up a review of the curriculum and its assessment in 1993, led by Ron Dearing. It resulted in national curriculum tests that were shorter than before and externally marked at key stages 2 and 3 (House of Commons, 2009). 
The average seven year old is expected to reach level 2 and the aim is to have students move up one level every two years. The programmes of study and attainment targets direct teachers on what they should teach and to what level. The intention is that the depth of knowledge, skills and understanding increases in each programme of study as students move on to higher stages.

All subjects are assessed through teacher assessments and progress is reported to parents every year. Teachers make summary judgements against the attainment targets at the end of each key stage. At the end of key stage 1 students must be assessed in English, mathematics and science. The emphasis is on teachers' judgements, but there are also external tests that teachers use in reading comprehension, spelling and mathematics. The tests, which examine achievement of the relevant elements of the national curriculum, are marked within the school and schools are allowed to decide when to administer them. All of the tests are criterion referenced. Results of the tests and teacher assessments are provided to parents and the public, and because of the latter, are used to judge school as well as student performance. Teachers' overall assessments are reported both to the local authority and to the DCSF. Aggregated school data are used to form an overall picture of local and national attainment.

Alongside teacher assessment, students must take statutory tests in English and mathematics at the end of key stage 2 as a key accountability measure for all primary schools. Up until 2009 they also had to take tests in science, but after the publication of The Report of the Expert Group on Assessment (DCSF, 2009h) the DCSF decided to abandon whole cohort testing of science at the end of key stage 2 in 2010. National standards in science at key stage 2 will be measured through a statutory sampling arrangement.

The English and mathematics tests are administered on set days each spring and test results are returned to the schools electronically. Each test takes about two years to develop and is trialled beforehand. The QCDA commissions outside agencies to develop the tests. The average student at the end of key stage 2 is expected to reach level 4 , and the government's goal for 2020 is to have $90 \%$ of students achieving this level in English and mathematics (DCSF, 2009a). The results of these tests are not used for secondary school selection. Schools are expected to set and publish performance targets for the percentage of students who will achieve levels 4 and 5 (DCSF, 2009e) and national performance tables list the percentage of eligible students who have obtained those levels. In $200980 \%$ of students reached level 4 in English; 79\% in mathematics; 88\% in science (DCSF, 2009c). 
Following an unprecedented hold up in the reporting out of key stage 2 and key stage 3 results (see below) the Secretary of State announced in 2008 the end of compulsory key stage 3 tests and the cessation of the publication of key stage 3 achievement and attainment tables. Prior to that students sat compulsory tests in English, mathematics and science. An ICT test was developed earlier in the decade, but abandoned. Achievement at the end of this key stage is now reliant on teachers' summative judgements across all subjects. The government has announced that external assessments through a national sampling might be undertaken (DCSF, 2009g). An average student is expected to achieve at level 5 or 6 by the end of the key stage. In 2007 (the 2008 test results were never published) 74\% of 14 year olds achieved a level 5 or above in English; 76\% in mathematics; and 73\% in science.

\section{Accountability and the target culture}

Political aims for the education system became increasingly public after 1996 when the government started to publish the results of the national curriculum tests. National newspapers published rank orders of schools based on test results, leading schools to scramble for ever higher places in national league tables.

In 1997 the new Labour government famously stated that its priorities were 'education, education, education', heralding an unbroken era of government influence over the national curriculum. It introduced literacy and numeracy strategies, which measured schools' success in those areas by the test scores their students achieved, as well as a target culture, mandating ever higher proportions of students reaching certain levels of attainment. National Curriculum assessment continued to be used for a variety of purposes: as a tool to raise standards; to ascertain individual students' progress; to judge individual teacher performance; to ascertain where intervention in a school was necessary; and to hold schools accountable (Stobart, 2008). National curriculum assessment remained fairly stable during the first ten years of Labour government, although there was rumbling in the background about how schools' desires to improve tests results, especially at key stage 2 , skewed teaching provision to those subjects tested and to those students on the borderline of attaining level 4 at key stage 2 and level $5 / 6$ at key stage 3 .

Some of the rumbling came from Parliament itself. The Children, Schools and Families Committee in May 2008 published a report on national testing that stated that 'national testing for school accountability has resulted in some schools emphasising the maximisation of test results at the expense of a more rounded education for their pupils' (House of Commons, 2008a). It claimed that teaching to the tests was widespread, narrowing teaching to English, mathematics and science and in particular those aspects that are tested, a fact 
that compromised teachers' creativity and children's access to a broad and balanced curriculum. While in principle supportive of national testing, it agreed with Paul Newton's arguments that national curriculum tests were used for too many purposes (Newton, 2007) and recommended that the current system should uncouple the multiple purposes of measuring pupil attainment, school and teacher accountability and national monitoring. Calling for further consultation on accountability measures, it also recommended that

the purpose of national monitoring of the education system, particularly for policy formation, is best served by sample testing to measure standards over time and that cohort testing is neither appropriate nor ... desirable for this purpose (House of Commons,2008a, para 186).

As outlined above, national curriculum tests are regulated by the DCSF, which authorises QCDA to develop and deliver the tests according to the secretary of state's current policy and Ofqual to monitor that development and delivery. A regulatory framework sets out general and subject criteria for each test, the regulatory requirements for delivering the tests and the programme and procedures by which they are monitored (Ofqual, 2009f). The purpose behind the framework is to ensure standards are maintained and to establish whether the assessments are valid, reliable, comparable over time, fair, manageable and effective in measuring student achievement. A code of practice complements the framework (Ofqual, 2009e), which ensures that assessments properly reflect the national curriculum and that the results are a true reflection of pupils' levels of attainment by specifying all necessary processes and procedures, such as those around test development, pre-testing arrangements, test security, test administration, marking and level setting as well as providing the rules for Ofqual's monitoring of the administration, development, delivery and reporting of the assessments.

Despite being a highly regulated curriculum and assessment system, unanticipated incidents do occur, one of which took place shortly after the Select Committee published its report on testing, which government had initially rejected (House of Commons, 2008b). The problem was not the tests themselves but their marking. Each year close to four million tests were taken in English, mathematics and science by 11 and 14 year olds. Managing the distribution and marking of this number of tests has proved challenging throughout their existence and in 2007 a new organisation, ETS Europe, took on the responsibility. Unable to mark and return the tests to schools on time, in June and July 2008 ETS and QCA came under fire from ministers, who claimed not to have known about the impending hold-up. While the vast majority of students and schools received their results with only a slight delay, 
some never received them. Ofqual immediately called for an inquiry, which the DCSF joined, turning it into a joint inquiry (Sutherland 2008). Scathing in its criticism both of ETS and QCA, both QCA's CEO and the Director of its testing arm, the NAA, were suspended and eventually dismissed. ETS had earlier been released from its contract; it paid back $£ 24.1$ million of the £39.6 million it had been paid (QCDA, 2008).

The most surprising, if indirect, outcome of this incident was the government's sudden abandonment of national curriculum tests at key stage 3, which Secretary of State Ed Balls declared in October 2008. He announced the appointment of an Expert Group on Assessment to look into key stage 2 tests but stated that for key stage 3 , after taking into account the Select Committee's report, he had decided that enough information was available from GCSE results to provide students and parents with individual feedback and for school accountability purposes. When the Expert Group made recommendations in May 2009 to retain key stage 2 testing in English and mathematics but move to teacher assessment in science, Balls accepted its advice. The press release on the report pulled together the changes to key stage 2 and 3 assessment, but did not mention the events of the summer before (DCSF, 2009h). Almost everyone, however, assumed that the policy shift that heralded the demise of key stage 3 tests was a result of those events, as reported in all major media outlets. ${ }^{\mathrm{vi}}$

\section{The qualifications system}

As with the national curriculum, the qualifications system that succeeds it for older students is highly centralised and regulated, with government influence that has increased over time. That influence is ostensibly less direct than with the national curriculum; instead third parties - the regulators who oversee the system and the awarding organisations that develop and implement the qualifications and their assessment - must react to the policies and practices of the government of the day. The following attempts to describe the system and give insight into the effects of government involvement.

There is a national curriculum for key stage 4, but the system shifts at that stage from a curriculum-led model to an examinations-led one, with almost all students embarking on one or more accredited qualification (Stobart, 1991). Rather than having a school leaving certificate, as is the case in many curriculum-led systems, students in England take individual, subject-based courses, usually of two years' duration, that lead to individual qualifications. The government measures its success in upper secondary education by the number of qualifications 16 and 18 year olds achieve and how well they do in them, which 
has led to ever increasing government regulation and involvement. This progressive extension of state control has proceeded under the assumption that government can be both effective and impartial, but as Wolf argues, it actually stifles genuine reform and innovation through a process of 'regulatory capture' in which the mutual self-interest of government, regulators and awarding organisations reduces competition and any incentive to innovate (Wolf, 2009). And because government is measuring its success through the performance of these agencies, it has a very strong incentive to control, as much as possible, their output.

Fourteen to 16 year olds have more flexibility in what they can study than younger students. They are required to follow programmes of study in English, mathematics and science and also must study citizenship, ICT, religious education, sex education and work-related learning. They are entitled to, but do not have to, study modern foreign languages, the arts, humanities subjects and/or design and technology. The introduction of subject choice allows this age group to pursue vocationally related courses should they chose to. Under former governments 14 to 16 year olds had to study languages, social sciences and D\&T and some would relish their re-instatement. There is no compulsory curriculum at all for post-16 students.

New curricular opportunities for secondary students were introduced following the 200514 19 Education and Skills White Paper (DfES, 2005). Its six main goals, which reflect the education policy priorities posited by Machin and Vignoles, were: providing a strong foundation at key stage 3; tackling low post-16 participation; ensuring that all students have a grounding in the basics of English and mathematics and the skills they need for employment; providing better vocational routes that equip students with the knowledge and skills they need for further learning and employment; stretching and challenging all young people, and re-engaging the disaffected.

To support these goals, government introduced or expanded new opportunities for this age group including: apprenticeship programmes both for 14 to16 year olds (Young Apprenticeships) and 16-25 year olds. The former allows students to pursue vocational studies for two days per week, while otherwise following the national curriculum; the latter allows young people to engage in paid work while pursuing vocational qualifications; the introduction of functional skills qualifications in English, mathematics and ICT; the introduction of new Diploma qualifications in 14 vocational and three general sectors/subjects; and incorporating more challenging material in GCSE and A level programmes. 
These goals are very much linked into the priorities of the government at the time of this writing, and could well change were there to be a different party in power in 2010 .

Although programmes of study are detailed within the national curriculum for 14 to16 year olds in the subjects mentioned above, key stage 4 and beyond is dominated by assessment through qualifications. Each qualification is graded separately, and while there is currently no overarching certificate at the end of compulsory schooling, government introduced a composite qualification called the Diploma in 2008. A qualifications framework, the National Qualifications Framework, which may be replaced by a Qualifications and Credit Framework (Ofqual, 2008), is currently in place that contains accredited qualifications from entry level (special educational needs) to level $8(\mathrm{PhD})$ across a number of subjects and sectors. The framework is maintained by Ofqual but the individual qualifications are produced and examined by independent awarding bodies.

Qualifications can be general (academic) or vocational and most qualifications are not age limited. Because the post-14 curriculum is flexible, it allows for qualifications beyond the national curriculum subjects; the post-16 curriculum is absolutely flexible and, for an individual student, defined by the qualifications s/he takes. At key stage 4 most students take level 1 and 2 qualifications, the most popular of which are the GCSEs. They are graded $A^{*}$ through $G$, although only a grade of $A^{*}$ through $C$ (level 2 ) is considered a good pass. The average number of GCSEs taken is about eight (JCQ, 2008), generally including English, mathematics and science, because these are compulsory subjects and also because schools are judged by how many of their students obtain five or more GCSEs grades $A^{*}$ to $C$ including English and mathematics. In 2009 almost $50 \%$ of students achieved five or more GCSEs (or the equivalent) at grade $A^{*}$ to $\mathrm{C}$ including English and mathematics. Almost $70 \%$ achieved five or more GCSEs (or the equivalent) grade $A^{*}$ to $C$ and $88 \%$ achieved five GCSEs (or the equivalent) grade $A^{*}$ to $G$ (DCSF, 2009c).

Post-16 students mostly study level 3 qualifications, which include Advanced Subsidiary (AS), A levels and a wide variety of vocational and vocationally-related qualifications. Most students take four or more AS levels in year 12 and complete three or more A levels in year 13. The AS is a free-standing qualification, but it also makes up the first half of an A level. $A$ levels are graded $A$ through $E$ (an $A^{*}$ grade will be introduced in 2010) and the pass rate is over $90 \%$. Vocational students are more likely to be studying at FE colleges and some work as part-time apprentices. 
Both GCSEs and A levels include internal and external assessment. Typically a GCSE will have $25 \%$ internal assessment, originally referred to as coursework but now, more tightly defined and managed, as controlled assessment. Controlled assessment regulations spell out the rules for how each subject's assessment is set, the conditions under which it is taken and how it is marked. In all cases, some of the assessment is taken under strictly supervised conditions. Some GCSEs in more applied subjects have 60\% controlled assessment; some, such as mathematics, have none at all. A typical A level will have $25-30 \%$ internal assessment, but some have none at all and more applied ones will have up to $67 \%$ internal assessment. Vocational qualifications typically have little, or no, external assessment (Ofqual, 2009c).

\section{Case Study in Standardising Assessment - the GCSE}

Increased centralisation has affected qualifications as well as the curriculum. Governments augment regulation of qualifications in the name of ensuring standards and comparability, and those are of great importance. But with increasing specificity comes a loss of teachers' professional control over what is taught and awarding bodies' ability to innovate. Whitty posits that education policy is all too often dominated by quick fixes and politicians' 'bright ideas' (Whitty, 2006, p. 168) and Baird and Lee-Kelley (2009) argue that politically driven education reforms often exacerbate issues and problems in qualifications development.

The evolution of the GCSE serves as a case study of these effects. As Kathleen Tattersall stated, 'GCSE seems to have been the Trojan horse which carried into the curriculum fortress so jealously guarded by teachers the ideologies of politicians of whatever political persuasion.' (Tattersall, 1994, p. 295). These qualifications, which combined content and standards from O levels - aimed at the top $20 \%$ of the cohort - and CSEs - aimed at the next $40 \%$ and that also met the needs of the bottom $40 \%$ were over a decade in the making. Spurred on by the raising of the school leaving age to 16 and by the fact that many students were leaving education without qualifications, the Schools Council worked on forming a single system of examinations during the 1970s. It did this in conjunction with the GCE and CSE examining boards (awarding bodies). In 1984 the Secretary of State for Education, Sir Keith Joseph, accepted the SEC's recommendation that a single system of examinations should be introduced, as long as the new qualifications were underpinned by qualification and subject specific criteria (of which he personally would approve), the standards of the $O$ levels (grades $A$ to $C$ ) and CSEs (grades 2 to 5 , subsequently $D$ to $G$ ) should be carried forward, and that most subjects should offer two or more tiers of assessment, each aimed at part of the cohort, and each based on positive achievement. (Torrance, 2002; Daugherty 
1995, Lambert and Lines, 2000) These are some of the foot soldiers that the Trojan horse let in. Specific changes to content, coursework and controlled assessment followed.

Joseph wanted 'grade-related criteria which will specify the knowledge, understanding and skills expected for the award of particular grades' (quoted in Tattersall 2007, p. 69), which would allow the examinations to cast off norm referencing and would support consistency across subjects, different awarding bodies' syllabuses and over time. His direct influence over the process marked a step change in government influence over curriculum and qualifications. After the late 1980s ministers and their civil servants in education departments were routinely involved in qualifications and curriculum decisions, even where technically the responsibility for either rested with the agencies listed above.

$A$ and $O$ levels had been norm referenced, that is, a certain proportion of the candidates were awarded certain grades. GCSEs aspired to change that and base the outcomes on the specifics of what each student had achieved in each subject. Criterion referencing was seen to be both fairer and more motivating for students. However, basing the grading of students on pre-specified criteria proved to be problematic. Attempts were made to develop subject criteria for each grade, but these were abandoned after the SEC's Grade Criteria Working Parties' efforts were acknowledged to be overly complex and unwieldy, with far too many performance statements (Tattersall 2007). Instead, grade descriptions were developed for just a few grades.

The SEC published GCSE national criteria in 1985 in 17 subjects. In the preamble to the publication the Secretary of State for Education for England and his counterpart in Wales stressed their importance:

We see publication of the national criteria as an historic step. For the first time, the partners in the education service have pooled their wisdom and experience in order to produce nationally agreed statements on course objectives, content, and assessment methods for all the subject areas most commonly examined in the final years of compulsory schooling (quoted in Daugherty 1995, p. 126).

SEAC published revisions to the criteria in 1990, SCAA published further revisions in 1995, and the QCA revised them further in 2000 and 2007-08. By 2009 the number of subjects that had criteria increased to 37 , allowing more uniformity, and potentially less innovation, across the vast majority of the courses that students take during key stage 4 . If more than 
one awarding body were going to offer a particular subject the regulatory authorities wanted that subject to have criteria associated with it.

GCSE subject criteria set out the knowledge, understanding, skills and assessment objectives common to all GCSE syllabuses in that subject. They provide the framework within which awarding bodies create the syllabus details. Those syllabuses must also meet the regulators' general requirements, including the common and GCSE criteria as defined in The statutory regulation of external qualifications in England, Wales and Northern Ireland (Ofqual, 2004). Subject criteria are intended to:

- help ensure consistent and comparable standards in the same subject across the awarding bodies

- ensure that the rigour of GCSE is maintained

- ensure that syllabuses build on the knowledge, understanding and skills established by the national curricula for England, Northern Ireland and Wales, and facilitate progression

- help higher education institutions, employers and other stakeholders such as learners and parents/guardians know what has been studied and assessed.

Each set of criteria elaborates upon:

- Aims and learning outcomes, which contain aspirational statements such as syllabuses should encourage learners to be inspired, moved and changed by following a broad, coherent, satisfying and worthwhile course of study and gain an insight into related sectors. They should prepare learners to make informed decisions about further learning opportunities and career choices. Additionally, this section indicates what the syllabuses must enable students to do in relation to the overall subject.

- Subject content, which specifies exactly what the syllabuses must cover, for example, the history criteria demand that each syllabus contains $25 \%$ British history and at least two different 'scales', such as local, national, European, international and global history. The English criteria require the study of at least one play by Shakespeare.

- Assessment objectives detail the areas and weightings on which students will be assessed, and generally follow a pattern of knowledge and understanding (25-35\% weighting), demonstrating understanding or skills (25-35\% weighting) and 
evaluation and analysis (30 - $40 \%$ weighting). Practical subjects are more heavily weighted to the demonstration of skills.

- Scheme of assessment outlines the balance of controlled and external assessment, and whether or not a subject is tiered. Subjects can contain either no, $25 \%$ or $60 \%$ controlled assessment.

- Grade descriptions describe typical performance, across the entire syllabus, at grades $A, C$ and $F$. All syllabi in a subject use the same grade descriptions, which the QCDA develops (Ofqual, 2009d).

GCSE qualification criteria were reworked in tandem with the subject criteria and with each revision regulatory control increased. For example, internally (teacher) assessed coursework, which in the early phase of the GCSE could be as high as $100 \%$ even in a high stakes subject such as English, was increasingly narrowed down both conceptually and in percentage weighting. In 1991 Prime Minister John Major, who did not approve of coursework because it left assessment judgements in the hands of teachers, stated that a maximum of $20 \%$ seemed right, which Tattersall characterises as an example of arbitrary politically driven change (Tattersall, 1994). Currently there are controlled assessment regulations for each subject governing the specific skills to be assessed, the setting of tasks, the extent of supervision in carrying out of tasks, the conditions under which assessment takes place, the marking of the assessment and internal standardising procedures. Awarding bodies must make clear how reliability and fairness are secured by setting out requirements that ensure the robustness of each stage of the controlled assessment (Ofqual, 2009c). It is not clear at the time of this writing what effect the increased regulation of internal assessment will have, but it is possible that it will erode even further teachers' contribution to what is taught and assessed.

The qualifications criteria are very specific about assessment arrangements and require that awarding bodies use a variety of question types and tasks, including extended writing, and assess the quality of written communication. Students are only allowed to re-sit each assessment component once and at least $40 \%$ of the assessment must be at the end of the course (Ofqual, 2009d). Each of these last two requirements was not made on the basis of increasing the validity or reliability of the examinations but because of public perceptions that re-sitting and modular assessment are both attempts to make the qualifications easier. vii

A levels regulation, which came about a few years later than GCSE, basically followed the same pattern and regulation has expanded to include newer qualifications such as vocational qualifications, the Diplomas and Functional Skills. The regulatory agencies 
control which syllabuses are accredited. The development timescale is protracted : revising criteria takes about four months, including a public consultation, development of the syllabi about six or seven months and the accreditation process another six months. The time available is not always sufficient to create inventive syllabuses, and Baird and Lee-Kelley (2009) argue that because the end date for qualifications development almost never shifts, it is the awarding bodies whose available time is generally truncated.

Most qualifications aimed at 14 to 19 year olds are also governed by codes of practice, the aims of which are to promote quality, consistency, accuracy and fairness in the assessment and awarding of qualifications, as well as help maintain standards across syllabuses both within and between awarding bodies and from year to year. To achieve this the codes set out the principles and practices for the assessment and quality assurance of qualifications; the roles and responsibilities of awarding bodies and centres; and the requirements for a high-quality examination process (Ofqual, 2009b). Ofqual uses the codes of practice to monitor awarding body practice and has the power to intervene if it judges that standards are not being upheld. Tattersall $(1994,2007)$ argues that awarding bodies' powers have been eroded through the increasing use of criteria, codes of practice, scrutinies (post delivery analysis of how well a qualification is working, which Ofqual runs) and Ofsted inspections.

Regulation was put in place for the best of intentions: to ensure comparability of standards across subjects, syllabuses and over time. It has meant, however, that the resulting syllabuses tend to look very much the same from one awarding body to the next because the content, assessment methods and assessment weightings are so tightly specified and because awarding bodies do not want to jeopardise their market share. External assessments (examinations) do not vary much from year to year and internal (controlled) assessments are now also the subject of precise rules. And certain ministerial shibboleths such as mental arithmetic in mathematics, cookery in design and technology, English history in history and Shakespeare in English, inevitably find themselves emphasised within the criteria, sometimes at the expense of other content and assessment. The regulatory system, as Wolf argues, has become moribund as 'government places ever more barriers in the way of entry, innovation, and flexibility' (Wolf, 2009).

\section{Conclusions}

Over the course of the second half of the $20^{\text {th }}$ century and into the $21^{\text {st }}$ both the national curriculum and its attendant assessments and the qualifications system have both benefited from and been hampered by the governmental pursuit of improving national standards. 
The pressure toward greater state control of education is constantly building up. England's secretaries of state for education are, by law, responsible for the national curriculum, including its content and assessment arrangements. While providing assurance that children in every part of the country are provided with similar curricular standards, ministerial notions about the mode of assessments, about target setting and about how outcomes should be reached have had a profound influence on primary and secondary education.

Criteria and codes of practice for national curriculum assessments and qualifications have been used to promote public confidence about assessment validity, reliability, manageability and standards over time. They have also meant a certain uniformity of assessment, especially in qualifications aimed at 14 to 19 year olds. There is currently no sign that this political influence will decrease.

\section{Notes}

' Local convention uses the term children for those aged 0 to 11; pupils for those aged 11 - 14 years and students for those 14 and older, this article will use the term student throughout to avoid confusion.

ii For a fuller history, see Tattersall, Kathleen, $A$ brief history of policies, practices and issues relating to comparability in Newton, $\mathrm{P}$, Baird $\mathrm{J}-\mathrm{A}$, Goldstein, $\mathrm{H}, \mathrm{Patrick}, \mathrm{H}$ and Tymms, $\mathrm{P}$, eds. Techniques for monitoring the comparability of examination standards. QCA, London 2007, pp $43-96$

iii Adapted from a table in Tattersall (2007)

iv Some parts of England have middle schools, catering to students in years 5 to 8 .

${ }^{\vee}$ Recommended at primary stage, compulsory for key stage 3

vi See, for example, coverage in the BBC, Guardian and Times, news.bbc.co.uk/2/hi/uk_news/education/7669254.stm;www.guardian.co.uk/education/2008/o ct/14/sats-scrapped; www.timesonline.co.uk/tol/life_and_style/...league.../article6737960.ece

vii See, for example, newspaper stories in the Daily Mail (www.dailymail.co.uk) 7 April 2008, the Telegraph (www.telegraph.co.uk) 15 February 2009 and the Guardian (www.guardian.co.uk) 17 August 2009.

\section{References}

Baird, J-A. and L. Lee-Kelley. (2009). The dearth of managerialism in implementation of national examinations policy. Journal of Education Policy, 24, 1: $55-81$.

Balls, E. (2008) Remit letter to Jim Rose, www.dcsf.gov.uk/pns/pnattach/20080003/1.pdf, (accessed 7 December 2009). 
Daugherty, R. (1995). National Curriculum assessment: a review of policy 1987-1994. London: Falmer Press.

Department for Children Schools and Families. (2008). The composition of schools in England, www.dcsf.gov.uk/rsgateway/DB/SBU/b000796/index.shtml (accessed 10 November 2009).

Department for Children, Schools and Families. (2009a) Children's plan, http://www.dcsf.gov.uk/childrensplan (accessed on 9 November 2009).

Department for Children, Schools and Families. (2009b) Gateway www.dcsf.gov.uk/rsgateway/D/SFR/s000865/index.shmtl (accessed on 9 November 2009).

Department for Children, Schools and Families (2009c) Good progress in GCSEs as overall $A^{*}-C$ rate rises to a record high http://www.dcsf.gov.uk/pns/DisplayPN.cgi?pn id=2009 0155 (accessed 10 December 2009)

Department for Children, Schools and Families. (2009d) The Independent Review of the Primary Curriculum http://www.dcsf.gov.uk/primarycurriculumreview (accessed 7 December 2009).

Department for Children, Schools and Families. (2009e) LA Target Setting. http://www.standards.dfes.gov.uk/ts/guidance/lea/ (accessed on 9 November 2009).

Department for Children, Schools and Families (2009f) Major report on school accountability and testing published by government expert group DCSF press release 7 May 2009, www.dcsf.gov.uk - Press Notice 2009/0090 (accessed on 11 November 2009).

Department for Children, Schools and Families. (2009g) Newscentre www.dcsf.gov.uk/newscentre (accessed 9 November 2009).

Department for Children, Schools and Families. (2009h) The Report of the Expert Working Group (http://publications.dcsf.gov.uk/, reference number DCSF-005322009) (accessed 11 November 2009).

Department for Children, Schools and Families. (2009i). Statutory framework for the Early Years Foundation Stage. http://nationalstrategies.standards.dcsf.gov.uk/node/151379 accessed on 6 November 2009

Department for Education and Science (1987) Task Group on Assessment and Testing Report (TGAT) London: DES

Department for Education and Skills (2005) 14-19 Education and Skills, www.dcsf.gov.uk/14-19/documents/14-19whitepaper.pdf (accessed on 6 November 2009). 
Gipps, C. (1993) The structure for assessment and recording, in Assessing the national curriculum (eds) P. O'Hear and J. White. 50 - 56 London: Paul Chapman Publishing.

House of Commons Children, Schools and Families Committee. (2008a) Third Report on National Testing, www/parliament.the-stationeryoffice.co.uk/pa/cm200708/cmselect/cmchilsch/169/16902.htm (accessed on 16 November 2009.

House of Commons Children, Schools and Families Committee (2008b) Testing and assessment: government and Ofsted responses to the Committee's third report of Session 2007-08, London: The Stationery Office.

House of Commons Children, Schools and Families Committee (2009) National Curriculum: fourth report of Session 2008-09, London: The Stationery Office.

International Review of Curriculum and Assessment Framework Internet Archive (INCA). (2009). INCA Summary Profile - Education in England. www.inca.org.uk/england-system-mainstream.html (accessed on 26 November 2009).

Isaacs, T. and I. Colwill. (2005). Education in England, from an unpublished paper for the Iraqi government

Joint Council for Qualifications (2008) Summer results press release 21 August 2008, www.jcq.org.uk. (accessed 8 December 2009).

Lambert, D. and D. Lines. (2000). Understanding assessment: purposes, perceptions, practice. London: Routledge.

Levin, B. (1998). An epidemic of education policy: (what) can we learn from each other? Comparative education 34, 2: 131-141.

Machin, S and A. Vignoles. (2006) Education Policy in the UK, London: London School of Economics

National Database of Accredited Qualifications. (2009) www.accreditedqualifications.org.uk. (accessed on 6 November 2009).

National Union of Teachers (2002) The Case Against Testing in England, www.teachers.org.uk/resources/pdf/case aganist testing.pdf (accessed on 24 December 2009)

Newton, P. (2007) Clarifying the purposes of educational assessment. Assessment in Education 14, 2: 149 - 170.

Office of Public Sector Information. (1988) Education Reform Act 1988, www.opsi.gov.uk/acts/acts1988/ukpga_19880040_en_1.htm (accessed on 7 December 2009). 
Office of Public Sector Information. (2009) Apprenticeships, Skills, Children and Learning Act 2009 www.opsi.gov.uk/acts/acts2009/ukpga 20090022 en 1 (accessed on 7 December 2009).

Ofqual (2004) The statutory regulation of external qualifications in England, Wales and Northern Ireland http://www.ofqual.gov.uk/files/6944 regulatory criteria 04(1).pdf accessed 10 December 2009.

Office of the Examinations Regulator. (2008). NQF and QCF. www.ofqual.gov.uk/518.aspx (accessed 9 November 2009).

Office of the Examinations Regulator (2009a) About Us, http://www.ofsted.gov.uk/Ofsted-home/About-us. (accessed on 6 November 2009).

Office of the Examinations Regulator (2009b) GCE, GCSE, Advanced Extension Award Code of Practice. http://www.ofqual.gov.uk/61.aspx, (accessed 16 November 2009)

Office of the Examinations Regulator (2009c) GCSE controlled assessment regulations. www.ofqual.gov.uk/2004.aspx (accessed 8 December 2009).

Office of the Examinations Regulator (2009d). GCSE qualification criteria www.ofqual.gov.uk/743.aspx - 17/07/2009, (accessed 16 November 2009)

Office of the Examinations Regulator (2009e) National Curriculum Assessments Code of Practice, Ofqual/09/4122.

Office of the Examinations Regulator (2009f) National Curriculum Assessments Regulatory Framework, Ofqual/09/4123.

Office for National Statistics. (2009). Estimated resident population by ethnic group and sex, mid 2007 (experimental statistics).

http://www.statistics.gov.uk/hub/population/index.html (accessed on 6 November 2009).

Office for Standards in Education, Children's Services and Skills (2009) http://www.ofsted.gov.uk/Ofsted-home/About-us. Accessed on 6 November 2009.

O'Hear, P. and J. White (eds) (1993) Assessing the national curriculum London: Paul Chapman Publishing.

Qualifications and Curriculum Development Agency. (2008). News release: national curriculum tests operations contract www.qcda.gov.uk/19029. aspx (accessed on 7 December 2009).

Qualifications and Curriculum Development Agency. (2009). What We Do, http://www.qcda.gov.uk/8710.aspx. (accessed on 6 November 2009). 
Ray, A. (2006). School value added measures in England. London: Department for Education and Skills.

Salter, B and T. Tapper. (1987). The Department of Education and Science - steering a new course, in GCSE: examining the New System, (ed) T. Horton, $21-28$. London: Harper and Row.

Stobart, G. (1991) GCSE meets key stage 4: something had to give. Cambridge Journal of Education 21, 2: 177 - 187.

Stobart, G. (2008). Testing Times: the uses and abuses of assessment. Abingdon: Routledge.

Sutherland, S. (2008) An Independent Inquiry into the Delivery of National Curriculum Tests in 2008: a report to Ofqual and the Secretary of State for Children, Schools and Families. London: The Stationery Office.

Tattersall, K. (1994) The Role and Functions of Public examinations. Assessment in Education, 1, 3: 293 - 304.

Tattersall, K. (2007). A brief history of policies, practices and issues relating to comparability in Techniques for monitoring the comparability of examination standards, (eds) Newton, P, J-A. Baird, H. Goldstein, H. Patrick and P. Tymms, P. 42 - 96. QCA: London

Teachernet. (2009). Attendance FAQs.

www.teachernet.gov.uk/wholeschool/behaviour/attendance/faqs/ (accessed 7 December 2009).

Torrance, H. (2002) Can education really raise educational standards? Delivered at the University of Sussex, 11 June 2002 www.enquirylearning.net/ELU/Issues/Education/HTassess.html (accessed 11/11/2009).

Whetton, C. (2009) A brief history of a testing time: national curriculum assessment in England 1988 - 2008. Educational Research 51, 2: 137 - 159.

Whitty, G. (2006) Education(al) research and education policy making: is conflict inevitable? British Educational Research Journal, 32, 2: 159 - 176.

Wolf, A (2009) The role of the state in educational assessment, paper delivered to the Cambridge Assessment Conference, Cambridge, 19 October 2009. 